\title{
Die kerklied en kommunikasie deur woord en melodie
}

\begin{abstract}
Author:
Jacoba H. van Rooy

Affiliation:

${ }^{1}$ School of Ecclesiastical Sciences, North-West University, Potchefstroom

Campus, South Africa

Correspondence to:

Jacoba van Rooy

Email:

herrie.vanrooy@nwu.ac.za

Postal address:

PO Box 19217, Noordbrug

2522, South Africa

Dates:

Received: 30 May 2011

Accepted: 08 Nov. 2011

Published: 18 Mar. 2013

How to cite this article:

Van Rooy, J., 'Die kerklied en kommunikasie deur woord en melodie', In die Skriflig/ In Luce Verbi 47(1), Art. \#82, 9 pages. http://dx.doi. org/10.4102/ids.v47i1.82
\end{abstract}

\section{Copyright:}

(C) 2013. The Authors.

Licensee: AOSIS

OpenJournals. This work

is licensed under the

Creative Commons

Attribution License.
Read online:

Scan this QR code with your smart phone or mobile device to read online. 'n Vraag wat min gestel word in die beoordeling van die funksie van gemeentelike sang is die vraag na die wisselwerking tussen die liedteks en die melodie. Hierdie wisselwerking speel 'n groot rol in die kommunikasie deur die lied in die erediens. In hierdie artikel word gelet op Skrifgegewens wat van toepassing is, op enkele perspektiewe uit die kerkgeskiedenis en op teoretiese aspekte van die kerklied en kommunikasie. Sekere sake uit 'n empiriese ondersoek, toegespits op die Gereformeerde Kerke in Suid-Afrika (GKSA), lig die saak verder toe. Predikante het 'n besondere verantwoordelikheid om die kommunikasiemoontlikhede deur die kerklied te bevorder deur 'n verantwoorde keuse van liedere wat gesing word, die uitbreiding van 'n gemeenterepertorium, sinvolle samewerking met die orrelis en toeligting van die liedkeuses.

The hymn and communication through word and melody. The interaction between the melody and the words of a hymn is not regularly taken into account in evaluating the function of congregational singing. This interaction is, however, very important for the communication effected by a hymn during a service. This article discusses Scriptural data important for this topic, some perspectives from church history and theoretical aspects of communication through hymns. Data from an empirical investigation directed at the Reformed Churches in South Africa (RCSA) sheds light on this topic. Ministers of religion have a special responsibility to enhance the possibilities of communication through hymns by their selection of hymns, the broadening of the repertoire of a congregation, meaningful cooperation with the organist and explaining the choice of hymns.

\section{Inleiding}

In die beoordeling van die funksie van gemeentelike sang is daar verskeie sake wat aan die orde kan kom soos watter liedere gesing word (net psalms, ander Skrifberymings, vrye liedere), hoe verskillende berymings beoordeel word en nog meer. 'n Vraag wat egter min gestel word, is die vraag na die wisselwerking tussen die liedteks en die melodie. Hierdie artikel gaan in die besonder aandag gee aan hierdie saak. Dit is duidelik dat in die kommunikasie wat deur die kerklied geskied, die wisselwerking tussen teks en melodie 'n groot rol speel. Eerstens gaan gelet word op Skrifgegewens wat van toepassing is, tweedens op enkele perspektiewe uit die kerkgeskiedenis, derdens op teoretiese aspekte van die kerklied en kommunikasie en laastens kom die empiriese gegewens aan die beurt. Alhoewel die empiriese ondersoek toegespits was op die Gereformeerde Kerke in Suid-Afrika (GKSA), het die bevindings wyer trefkrag.

\section{Kommunikasie deur woord en lied vanuit 'n bybelse perspektief}

In sowel die $\mathrm{Ou}$ as die Nuwe Testament is gedeeltes wat op die belangrike wisselwerking tussen teks en melodie dui. Musiek gee innerlike rus en dít stel die hart oop vir God se planne (bv. 1 Sam 10:5; 2 Kon 3:11-19; 1 Kron 25). Die besondere verbinding tussen profesie en musiek in 2 Konings 3:15-16 is uniek in die Ou Testament en dui op een van verskeie maniere waarop 'n profeet sy boodskap van die Here ontvang het (Hobbs 1985:36; House 1995:263). Deur die musiek van die Leviete (1 Kron 25) het God sy wil aan die volk bekend gemaak, waarop hulle Hom geloof en gedank het (Thompson 1994:177).

Die lees van die Tora met deurlopende psalmgesang dui daarop dat die twee elemente, woord en lied, hand aan hand gaan. Albei het die verkondigingskrag van woord en antwoord (Kloppers 2003b:68-69). Die Skrif maak dit duidelik dat groot gedeeltes uit die Ou Testament in die tempel (en later in die sinagoge) op verhoogde toon voorgedra is; liedere het in die geskrewe of gelese teks gefunksioneer. Dikwels is bekende liedere in die teks ingevoeg. Soms is ' $n$ hele profesie as een digwerk of lied beskou (Vrijlandt 1987:25). Liedere en gebede is nie beperk tot 
die psalms nie (Box 1996:3). Die boek van die Psalms is 'n versameling godsdienstige poësie. By ander Ou-Testamentiese Skrifgedeeltes word ook gedigte of liedere aangetref, byvoorbeeld 'Die lied van die see' (Eks 15:1-18), 'Die lied van die ark' (Num 10:35-36), 'Die lied van Moses' (Deut 32), 'Die seën van Moses' (Deut 33), 'Die lied van Debora' (Rigt 5) en 'Die lied van Hanna' (1 Sam 2:1-10; Craigie 1983:25; Vrijlandt 1987:25). Die liedere is in die verhalende gedeeltes van die Ou Testament ingevoeg om die boodskap van die betrokke boek te beklemtoon en te belig.

Op grond van sy eksegese van 'Die lied van die see' (Eks 15:1-18) het Bingle (2000:34-35) 'n aantal belangrike basisteoretiese riglyne geformuleer. Hieruit is dit duidelik dat liturgiese sang verband hou met God se openbaring, dat die gemeente in die sang op sy openbaring antwoord en dat die gemeenskaplike aard van liturgiese sang van groot belang is.

In die Nuwe Testament het die lied 'n rol gespeel in die erediens van die Vroeë Kerk, wat bygedra het tot die gemeenskaplike aanbidding en versterking in die geloof. In 1 Korintiërs 14:26 word onder meer na psalms verwys as deel van die dinge wat tot die opbou van die gemeente moet dien (Van der Leeuw \& Bernet Kempers 1939:31; Vrijlandt 1987:35). Liedere het ook belydenisse uitgedruk (Viljoen 1990:8). Van die nuwe lied (waarna sommige psalms heenwys) kan gelees word in Openbaring en die briewe van Paulus. Sagaria, Elisabet en Maria het die koms van die Messias singend aangekondig en so ook die engele in Lukas 2:14 (Schelling 1989:26; vgl. Viljoen 2001:9). Kort voor sy kruisdood het Jesus en sy dissipels tydens die Pasga Psalm 113-118 gesing. Met die klaagliedere van die psalmdigters op sy lippe het Hy gesterf. Na die uitstorting van die Heilige Gees was die nuwe gemeenskap singend byeen. Lied en spel gee aan die messiaanse gemeenskap krag vir vandag en hoop vir môre (Schelling 1989:15). Volgens Viljoen (2003:216) kan agt himnes in Openbaring onderskei word. Hierdie liedere vervul 'n narratiewe funksie (Viljoen 2003:219) waarin die alleenheerskappy van God sterk beklemtoon word (Viljoen 2003:232) en het die kommunikatiewe effek van die res van die narratief versterk (Viljoen 2003:233; vgl. ook Viljoen 2002 vir die himnes in Op 12-22).

Dit is duidelik dat liedere in die bybelse tyd gebruik is om die kommunikasie van die boodskap te bevestig en in te skerp. In die volgende afdeling word die saak vanuit die kerkgeskiedenis belig.

\section{Kommunikasie deur die woord en die lied vanuit 'n historiese perspektief \\ Die Vroeë Kerk}

Die Vroeë Kerk het die eenvoudige psalmodie van die sinagoge aanvaar en dit óf uitgebrei soos die liturgie meer geformaliseer is deur die edik van Milaan, óf deur dreunsang (chants) op sekulêre tekste te baseer. Dit is moontlik dat die Septuagintweergawe van die psalms op melodieë gesing is wat van die Hebreeuse tradisie geleen is (Box 1996:17). Christelike psalmsang het ongeveer in die derde eeu ontstaan onder die invloed van die opkomende Egiptiese en Palestynse monnikedom (Zijlstra 2001:14). Sedert die tyd van Karel die Grote het die deelname van die gemeente na vore gekom. Tydens gebede word akklamasies en response gehoor (oorblyfsels van die sinagoge). Hier lê die wortels van die gemeenskaplike viering van die liturgie. By die psalms het die gemeente die antifone saamgesing (Vrijlandt 1987:75). Ambrosius het 'n groot rol in die ontwikkeling van sang gespeel. Uit die konflik van sy tyd het die eintlike kerklied ontstaan (Möller 2000:27). In sy psalmkommentaar tree sy liefde vir die kerklied op ' $n$ besondere wyse na vore. Hierin tipeer hy psalmsang as die beste belydenis, die hoogste vreugde, die diepste vroomheid en die veiligste beskerming. Deur te sing, het elkeen medeseggenskap in die kerk; ook die vroue en die jeug leer hierdeur die waarhede van die geloof (Schulte Nordholt 1977:1130).

\section{Die Middeleeue}

In die Middeleeue het die plek van gemeentesang gekwyn. Algaande het dit verskraal tot responsies. Sekere liedere het tog ' $n$ vaste plek in die liturgie van die Katolieke Kerk gekry deurdat dit hoofsaaklik aan kore toegewys is, aangesien die tegniese vereistes van die liedere te hoog geraak het. Die geringe aandeel van gemeentesang in die erediens kan toegeskryf word aan die feit dat die kerktaal Latyn was, wat vir die meeste gewone lidmate ontoeganklik was. Buite die erediens om het geestelike volksliedere egter ontwikkel wat ten dele beskou kan word as die voorloper van die reformatoriese kerklied.

\section{Die Reformasie}

Vir reformatore soos Luther en Calvyn het die funksie van die lied ten nouste saamgehang met die diens van die gemeente in die erediens. Die lied was nie net ' $n$ versiering of opluistering van die erediens nie, maar 'n wesenlike deel ter verryking van die erediens. Hulle het die noue verhouding tussen woord en musiek as 'n kenmerk van die erediens beklemtoon. Wanneer hierdie verhouding tot sy reg kom, bevorder dit die moontlikheid dat die lidmate se belewing van die liturgiese handelings versterk kan word (Kloppers 2003a:12). Luther se standpunt was dat musiek 'n belangrike genadegawe van God is en daarom ook 'n wesenskenmerk van die kerk is. Hy was daarvan oortuig dat musiek die beste middel is om geloof te verklank. Prediking was dus nie die enigste middel waardeur die goddelike openbaring verkondig is nie; ook deur musiek kan 'n gemeente verkondigend betrokke wees. Volgens Luther het musiek twee funksies, naamlik om die Woord te verkondig en om as uitdrukking van die geloof te dien (Kloppers 2003a:12). Calvyn het gemeen dat die musiek prinsipieel ten dienste van die teks moes staan (Kloppenburg 2002:115).

Die woord-toonverhouding in die Geneefse Psalter het twee uitstaande eienskappe. Die eerste eienskap is die merkbaar oorhoofse verwantskap op grond daarvan dat die komponis(te) probeer het om deur middel van toonsoortkeuse 
en melodiestruktuur die teks as geheel te onderstreep. So byvoorbeeld word psalms met ' $n$ smekende karakter van 'n frigiese melodie voorsien met hoofsaaklik 'n diatoniese verloop, byvoorbeeld die Geneefse melodie van Psalm 51. 'n Uitbundige lofprysing kry die outentieke doriese modus met lewendige ritme, toonherhalings en groter intervalle soos die Geneefse melodie van Psalm 107. Die tweede eienskap is die verhouding tussen spesifieke woorde en die bybehorende intervalle soos dit voorkom in die Geneefse melodie van Psalm 130 (Kloppenburg 2002:119).

\section{Die periode na die Reformasie}

Die Souterliedekens wat in 1540 in Antwerpen verskyn het, het in 'n groot behoefte voorsien. Die taal en die versvorm was eenvoudig, sodat die volk daardeur geraak is (Van Andel 1982:143). Hoe sang in Nederland teologies gefundeer is, kan afgelei word uit die voorredes van die psalmberymings van Utenhove, Datheen en Marnix. Utenhove se weergawe wys die tweeledige funksie aan, naamlik dat deur sang lof en dank aan God gebring word terwyl dit ook verkondiging by die mense uitbring. Volgens Datheen is die inhoud uiters geskik in tye van vervolging; dit bevat danksegging, lofprysing, gebede en klaagliedere. Daarbenewens bewerk dit versterking van die geloof. Vir Marnix kan psalms op enige plek gesing word. Sang dien tot versterking van die geloof en tot lofprysing aan God. Musiek beïnvloed mense en 'n teks dring veel dieper deur wanneer dit gesing word. Sowel teks as melodie is belangrik. In die psalms word alles gevind wat vir die geloof belangrik is. Datheen en Marnix onderskryf albei Calvyn se teologie, naamlik dat die lied en die melodie 'n verkondigingsfunksie het (Luth 1986:94-97).

Na die Reformasie het 'n skeiding tussen die digter en die musikus gekom, wat tot spesialisasie gelei het. So het die melodie die woord gewoonlik meer effektief gedien (Mudde 1977:91) soos in die liedmelodieë van Crüger (Mudde 1977:92). Die geheim van die vitaliteit van die Lutherse kerklied, volgens Mudde (1977:109), is daarin geleë dat dit nooit aan enige kerklike of andersins beperkende maatreëls onderworpe was nie. Daardeur het die Skrifgebonde vryheid waarbinne dit ontwikkel het, dikwels die beste na vore gekom. In die lewenskragtige kerklied is die melodie nie net 'n soort omhulsel van die teks nie. Die lied moet van die gegewe woord uitgaan en die bedoeling van die teks na vore probeer bring, maar die melodie kan 'n eie bydrae lewer om die inhoud beter te laat kommunikeer.

\section{Die teenswoordige tyd}

Hoondert (2003) bespreek die ontwikkeling van die woordtoonverhouding oor die afgelope 30 jaar. Volgens hom het die ontwikkeling van liturgiese liedere 'n golfbeweging verteenwoordig. Voor die tagtigerjare in die twintigste eeu was die teks die fokuspunt. Daarna tree die taal van die musiek meer op die voorgrond. Die melodie dien nie net die teks nie, maar verklank dit op 'n eie wyse (Hoondert 2003:72).

Die kerklied van vandag sal met die postmoderne mens rekening moet hou. Goeie geestelike liedere het 'n redelike lewensduur en invloed, maar om uit geykte historiese situasies liedere vir mense in ' $n$ ander lewensmilieu aan te bied, is fataal. Van der Colf meen dat ' $n$ belangrike aspek van die postmoderne tyd die Afrikanisering van die Afrika-mens is. Sang en beweging is deel van die Afrikaan. Mense moet hiervoor oop wees. Uit kontak met mekaar sal nuwe liedere tot eer van God en tot uitbouing van verhoudings vloei. In liedere wat tred hou met die huidige tydvak is die misterie van God, die wonder van sy genade en aktiewe beheer oor die hele skepping aktueel (Van der Colff 1997:21). Deur die kerkmusiek word die individu en die gemeenskap in die erediens verenig (Bunners 1995:834).

In die vorige twee afdelings is die saak van kommunikasie deur die teks en die melodie vanuit die Skrif en die kerkgeskiedenis belig. In die volgende afdeling word teoreties hieroor besin.

\section{Die kommunikasie deur die teks en die melodie van liedere}

Dit is onmoontlik om in 'n studie van hierdie omvang omvattend aan 'n teoretiese bespreking van kommunikasie in die algemeen aandag te gee. Erasmus (2007) bied 'n goeie oorsig hieroor. Hy onderskei vier belangrike modelle. In die klassieke retoriese model dra die spreker 'n argument aan sy hoorders voor, maar hierin kom die rol van die hoorder nie tot sy reg nie (Erasmus 2007:195-196). Die tweede model is die lineêre model, waarin die mededeler, die boodskap en die ontvanger onderskei word, met 'n eenrigingverkeer van die mededeler na die hoorder (Erasmus 2007:196-197). In die sirkulêre model kan die hoorder reageer en vrae vra, waardeur die hoorders sprekers word en die sprekers hoorders. In die dialogiese model is daar meer plek vir interaksie en die hoorder se voorverstaan (Erasmus 2007:186). In die kerkmusiek, veral in gemeentesang, speel die laaste twee modelle 'n rol, omdat die hoorders (die lidmate) aan die boodskap deelneem wanneer hulle sing.

Mehrtens (1982:103) oordeel dat die pedagogiese stelling: 'tekste word beter onthou op gesonge wyse', nie van mense kom nie. In Deuteronomium 31:19 rig God hom tot Moses, net voor sy dood: 'Teken hierdie lied vir julle op en leer dit vir die Israeliete. Laat hulle dit sing sodat die lied my getuie teen hulle kan wees.' Kommunikasie geskied nie deur taal alleen nie, maar ook deur musiek. Smit (2007:178) beskou musiek as een van die grondvorms van menslike kommunikasie. Sang in die erediens moet nie net tot die mens se antwoord gereduseer word nie, want sing en sê is twee verskillende wyses waarop taal uitgedruk word (Kloppers 1997:187). Die gelowige sing omdat hy God ontmoet, sy Woord hoor, in sy ganse wese aangeraak word en uitdrukking gee aan sy totale geloofservaring (Kloppers 2003a:13).

Barnard omskryf die gemeenskapsvormende krag van die kerklied as die 'communio-bevorderde', of die 'communiebewerkende' krag van die lied. Hy maak 'n aantal stellings oor die kerklied wat hierby aansluit (Barnard 1991:14-16). Die lied is die asem van die gemeente. Kerksang bring die kind van God in gemeenskap met almal wat Hom dien, op die aarde en in die hemel. Volgens Barnard word nou reeds met die engele van vóór die begin van die mensheid 
en met die saliges van ná die einde deur middel van die lied gekommunikeer. Kultuur neem die $e k$ as uitgangspunt. Hierteenoor kan die lied bevrydend werk, omdat dit samesang is. Vos en Müller (1990:87) stel dit dat binne so 'n konteks sprake is van die gemeente as draer van die lied en die lied as vertolker van die evangelie. Die gemeente kan dus aktief aan die erediens deelneem en sodoende diens aan God lewer.

Met die sang van die lidmate in die erediens kom geloof, musiek en poësie bymekaar, wat die onderlinge geloofsbelewenis bevorder (Du Plooy 2006:42). Volgens Steinmann (1996:15) is gemeentesang iets waardeur die gemeente aan die erediens deelneem en met God kommunikeer. Sodoende kom daar dialoog tussen Hom en sy gemeente. Hy praat deur die Woord en die prediking met die gemeente; die gemeente antwoord daarop met gebed en belydenis. ' $n$ Wyse waarop hierdie gebed en belydenis sinvol en ordelik uitgespreek word, is met gemeentesang. Sang in die erediens is die een manier waarop die gemeente in die besonder aktief besig is (Smit 1999:38). Daar kan dus nie twyfel wees oor die waarde wat musiek het om godsdiens vir die gelowige ' $n$ werklikheid te maak en die bybelse waarheid in die hart van die deelnemer in te dra nie (De Klerk 2002:60). Die kuns, waaronder die kerklied, poog steeds om van die waarnemer 'n deelnemer te maak (Kloppers 1997:106).

Schelling (1989:16) oordeel dat wanneer 'n mens bewus is van die sterk invloed wat van musiek uitgaan, sy kommunikatiewe aard en die besef dat musiek in die Skrif 'n sentrale rol speel en ook aanvaar dat musiek vir die jonger generasies min of meer ' $n$ leefwyse is, sal die vraag na musiek in kerklike werk nouliks verwondering wek. Om te kan sing, is een van die grootste gawes wat die Here aan die mens gegee het. Wanneer almal tydens die erediens saamsing, word hierdie gawe tot sy eer en tot opbou van mekaar aangewend (Kruger \& Smit 2001:16).

Speelman (2002) het probeer om liedere semioties te ontleed. Musiek is nie betekenisloos soos baie mense geneig is om te dink nie. Musiek sê iets; dit produseer betekenisvolle verbande en skep sin (Speelman 2002:132). Die ontmoeting van taal en musiek en albei se vermoëns om betekenis te genereer, vind by uitstek in die lied plaas (Speelman 2002:133). De Wit (1996:48) stel dit duidelik dat musiek gedagtes kan uitdruk wat die woord nie kan sê nie. Dit is net musiek wat kan sing van dit wat nie uitgespreek kan word en nie bepaalbaar is nie. Musiek kom die geloofswoord te hulp in sy magteloosheid om die dinge wat ongesê is, uit te druk. Musiek gee op sy eie manier uitdrukking aan die geloof. Sang in die erediens moet beskou word as die verkondiging van die lof van God, die verklanking van sy Woord en die verkondiging van sy boodskap. Hieruit blyk duidelik dat kommunikasie deur die kerklied deur woord en musiek behoort te geskied.

Speelman (2002:134) wys op die fundamentele verskil tussen die wyse waarop musiek betekenis het en die wyse waarop tekste iets oordra. Die verskil lê daarin dat musiek die werklikheid toon en laat beleef, terwyl taal die werklikheid wys. Tekste bring die wêreld agter die masker van konsepte wat ter sprake is; tekste lê beelde daaroorheen sodat in taal nie die wêreld nie, maar talige beelde van die wêreld waargeneem word. In musiek word die wêreld getoon deurdat musiek dit horend ontvang, daarna geluister word en die hoorder in die musiek opgaan. Dit lyk nie altyd of die musiek uitbeeld wat die teks sê nie, musiek en teks sê eerder iets vergelykbaars: dit praat as ' $t$ ware parallel met mekaar en versterk op hierdie wyse mekaar se boodskap (Speelman 2002:145). Die wyse waarop die teks en die musiek mekaar versterk (of nie), het te make met die woord-toonverhouding. Hierdie verhouding is die verhouding tussen die melodie en die woorde van 'n lied. Hierdie saak kan ongelukkig nie volledig hier bespreek word nie. Vergelyk in hierdie verband Van Rooy (2009:274-290).

Lamberts (2000:246) maak die belangrike opmerking dat die woord-toonverhouding na gelang van die doelstelling kan verskil. Musiek by die Ons Vader sal 'n dienende rol vervul, omdat dit bedoel is om die woorde te dra en die gemeenskapsgebeure, die samehorigheid as kinders van dieselfde Vader, te bevorder. Musiek by die Halleluja van Psalm 150 kan vryer en spontaner wees aangesien dit God se lof besing. Tussen hierdie twee tipes moet die woord en die teks mekaar vind sodat dit op mekaar kan inspeel. Die lidmaat moet deur die musiek aangeraak word en aktief aan die geloofsgemeenskap kan deelneem, wat 'n belangrike onderdeel van die kuns is om saam te vier. Die ideale omstandighede (Lamberts 2000:248) sou wees as teks en musiek hand aan hand gaan en mekaar dra. Dit is egter algemene kennis dat dit ' $n$ huwelik is waarin dikwels spanning ontstaan.

Vernooij (2002:106) wys daarop dat protestante oor die algemeen meer op die teks ingestel is as mense in die katolieke tradisie. Tog word psalms dikwels ter wille van die melodie opgegee en nie vanweë die teks nie. Die teks self speel by die vierende gemeente op twee maniere ' $n$ rol. Dit gee eerstens fundamenteel gestalte aan die taal van die melodie. Die melodie onderdruk nie die teks nie, maar vorm dit vanaf papiertaal om na feesvierende taal. Tweedens lei dit daartoe dat die geproklameerde klanke van die teks in die ekspressiewe krag van die melodie opgeneem word. Dit is 'n wesenlike onderdeel van die kerklied.

Melodieë wat vir liedere gebruik word, moenie die betekenis en verstaanbaarheid van die woorde versteur of versluier nie. Die melodie moet uitdrukking gee aan die inhoud, die woorde duideliker onderstreep en makliker laat ingang vind in die verstand en harte van lidmate of gemeentes. Dit is hierdie vermoë van musiek wat die woordinhoud soveel kragtiger laat inslag vind (Steinmann 1996:17).

Hull (2002) het in hierdie verband 'n interessante eksperiment gedoen. Hy het die bekende teks van Amazing grace gebruik en dit, naas die oorspronklike, op verskillende melodieë laat sing. Uit hierdie voorbeelde het hy tot ' $n$ aantal belangrike gevolgtrekkings gekom (Hull 2002:24-25). Die invloed van musiek, selfs relatiewe swak musiek, op die wyse waarop die teks begelei en verstaan word, is onvermydelik. Telkens wanneer 'n ander melodie vir dieselfde teks gebruik word, word op 'n ander wyse gekommunikeer. 'n Lied is nie teks 
of melodie alleen nie, maar die produk van die wedersydse interaksie van teks en melodie op mekaar. Die interpretasie wat deur die interaksie van die teks en die melodie ontstaan, word nie in 'n lugleegte beleef nie, maar binne liturgiese, kulturele, sosiale en ander groter kontekste. Die plasing van 'n lied binne die liturgiese struktuur bepaal hoe dit geïnterpreteer gaan word, byvoorbeeld tydens 'n doop, 'n begrafnis of 'n normale erediens. Die betekenis wat tydens aanbidding deur die teks en die musiek geskep word, druk nie net die spiritualiteit van die gemeente uit nie, maar vorm dit ook. Musiek is 'n nierasionele, nie-verbale medium. Dit word met 'n sintuiglike en verbeeldingryke onmiddellikheid beleef wat meer geredelik op die dieper lae van die gedagtes en gees inwerk.

Samevattend kan met die gevolgtrekking van Vos en Müller (1990:88) saamgestem word, naamlik dat die melodie die inhoud van die teks so moet laat spreek dat dit die totale mens, emosioneel en intellektueel, tot oorgawe oorreed. Hulle beklemtoon die funksie van die melodie as draer van die lied. Die melodie het ' $n$ dienende funksie en moet die gemeente help om met die teks te identifiseer. Identifikasie vind plaas wanneer die gemeente deur die melodie tot oorgawe aan die teks beweeg word.

Volgens Thevelein (2004:139) word die onsienlike in die liturgie gesien, die onnoembare genoem, uitgedruk wat nie uitgedruk kan word nie en uitgebeeld wat nie uitgebeeld kan word nie. Musiek bied die moontlikheid om vorm te gee aan wat nie uit te druk is nie. Daarom kan gesê word dat sing twee keer so goed is as om te bid. Die doel van musiek in die liturgie is om God te eer en die heiliging en opvoeding van die gelowige te bevorder. Saam sing en saam na musiek luister, vorm gemeenskap. Dit geskied op twee maniere: musiek bind mense saam deurdat hulle saam hulle stemme verhef of luister en dit verenig mense deur die aandag op 'n bepaalde inhoud, tema, gedagte of emosie te rig (Thevelein 2004:140). Liturgiese sang moet diensbaar wees ten opsigte van die teksinhoud en die melodie sodat die verkondigingsboodskap sentraal staan (Thevelein 2004:142).

Musiek word gebruik om die vreugdeboodskap van die evangelie te begelei en te verklank (Smit 1999:58). Hierby voeg Kloppers (2003a:13-15) die saak van assosiasie wat deur die musiek geskep word en wat'n sterk verkondigende funksie het. 'n Voorbeeld hiervan is tydens 'n sterfbed waar die woorde van 'n lied nie meer logies bedink kan word nie, maar waar die melodie van 'n lied nog deur middel van assosiasie 'n vertroostende en geloofsversterkende funksie kan hê. 'n Koraalverwerking of voorspel van 'n bekende psalm of lied herinner aan die woorde daarvan. Iemand wat gereeld eredienste bygewoon het, maar later verhinder word, kan deur musiek aan 'n erediens herinner word en so weer iets van die evangelie beleef.

Die teoretiese besinning van hierdie gedeelte vorm die basis waarop die empiriese ondersoek, wat in die volgende afdeling aan die orde kom, berus.

\section{'n Empiriese ondersoek na die kommunikasie deur die lied in die erediens}

In 2008 is 'n empiriese ondersoek onder predikante, orreliste en lidmate van die GKSA gedoen oor verskillende sake wat met die gebruik van die Psalmboek 2003 verband hou (Van Rooy 2009). In hierdie ondersoek is aan verskeie sake aandag gegee wat belangrik is vir die kommunikasie deur die lied in die erediens. Hierdie saak sal in hierdie afdeling bespreek word aan die hand van die bevindings van die ondersoek. Vraelyste is aan predikante, orreliste en lidmate van verskillende gemeentes gestuur en onderhoude is met ' $n$ aantal predikante en orreliste gevoer.

'n Vraag wat aan lidmate en orreliste gevra is, het oor die praktiese aspek van die kommunikasie deur die kerklied gehandel. Die respondente moes nadink oor die liedere wat tydens die laaste erediens wat hulle bygewoon het, gesing is. Daarop kon hulle aandui met watter van 'n aantal stellings hulle saamstem (vgl. Van Rooy 2009:414). Die reaksie word in Tabel 1, Beoordeling van die keuse van liedere, weergegee.

Die positiewe reaksie op die sing van die liedere tydens die erediens blyk veral uit die antwoorde op die tweede en derde moontlikhede genoem in Tabel 1, wat daarop wys dat die inhoud van die liedere wel op die respondente 'n impak gemaak het. Die volgende drie moontlikhede het in die besonder te doen met die verhouding tussen die melodie en die teks, waaroor ook positief geoordeel is, hoewel minder van die respondente daarop gereageer het. Die laaste moontlikheid is ook belangrik en wys tot hoe 'n mate die liedere die respondente tot refleksie gedwing het. Hier was by die lidmate ' $n$ meer positiewe reaksie as by die orreliste. Dit is egter verstaanbaar, aangesien die orreliste op hulle spel moes konsentreer. Die reaksie op hierdie vraag dui wel op 'n positiewe gesindheid ten opsigte van die impak van die liedere op die lidmate en die orreliste.

Vir die sukses van die kommunikasie van die kerklied behoort daar goeie samewerking tussen die liturg en die orrelis te wees, sodat die melodie wat vir die erediens gebruik gaan word, vroegtydig uitgeklaar word (Steinmann 1996:17). Dit kan vir die orrelis sinvol wees om vooraf met die liturg in gesprek te tree om uit te vind hoe die verloop en aard van die erediens gaan wees. Indien dit nie moontlik is nie, moet die musiek op die gegewe psalms en Skrifberymings afgestem wees.

TABEL 1: Beoordeling van die keuse van liedere.

\begin{tabular}{|c|c|c|}
\hline Stellings & Lidmate & Orreliste \\
\hline Ek kan nie onthou wat ons gesing het nie & $11 \%$ & $0 \%$ \\
\hline Die woorde van die liedere het my aangespreek & $74 \%$ & $79 \%$ \\
\hline $\begin{array}{l}\text { Ek kan verstaan hoekom die predikant die liedere laat } \\
\text { sing het nie }\end{array}$ & $70 \%$ & $79 \%$ \\
\hline Die melodieë pas by die woorde & $41 \%$ & $55 \%$ \\
\hline Die melodie ondersteun die woorde & $35 \%$ & $61 \%$ \\
\hline Die melodie en woorde vorm 'n eenheid & $42 \%$ & $55 \%$ \\
\hline $\begin{array}{l}\text { Die redes waarom ons die meeste van die betrokke } \\
\text { liedere gesing het, is vir my onduidelik }\end{array}$ & $3 \%$ & $6 \%$ \\
\hline $\begin{array}{l}\text { Ek het bewustelik oor die woorde nagedink terwyl die } \\
\text { liedere gesing is }\end{array}$ & $59 \%$ & $42 \%$ \\
\hline
\end{tabular}


Vir effektiewe kommunikasie deur die woord en die melodie is dit noodsaaklik dat orreliste genoeg geleentheid gegun word om hulle behoorlik vir die erediens voor te berei. Die predikante is gevra wanneer hulle normaalweg die liturgie vir Sondae se erediens(te) aan die orrelis gee (Van Rooy 2009:441). Die respons word in die paragrawe na Tabel 2, Liturgiese besonderhede van predikant na orrelis, weerspieël.

Die orreliste se respons hierop word in Tabel 3, Liturgiese besonderhede deur orrelis ontvang, weergegee (Van Rooy 2009:441).

Dit is opmerklik dat die predikante (Tabel 2) meen die inligting word vroeër beskikbaar gestel as wat die orreliste dit ervaar. By die orreliste (Tabel 3) was daar 'n aparte afdeling vir direk voor die erediens, wat deur $22 \%$ aangeteken is. Dit is ongeveer dieselfde getal as die predikante wat aangedui het dat hulle dit Saterdag of Sondag gegee het. Die gebruik om liturgiese gegewens op 'n laat stadium deur te gee, verhoed orreliste om behoorlik vir die erediens voor te berei, en dit het 'n negatiewe uitwerking op die kommunikasie deur die liedere tydens die erediens.

Die predikante, orreliste en lidmate is gevra om te oordeel watter faktore die keuse van liedere vir die erediens bepaal. Hulle kon meer as een moontlikheid merk. Die respons word in Tabel 4, Faktore wat die keuse van liedere bepaal, weergegee.

Dit is duidelik dat al drie groepe oordeel dat die eerste drie faktore die swaarste weeg, met die bekendheid van die melodie as die derde in rangorde by almal. Indien die groot hoeveelheid liedere in die Psalmboek (2000, 2003) wat nie gesing word nie (vgl. Van Rooy 2009:370) in aanmerking geneem word, weeg hierdie faktor waarskynlik swaarder as wat die respondente self dink. Die predikante laat hulle deur die eerste twee faktore lei, maar word dan beperk tot liedere wat die gemeente, na hulle oordeel, kan sing.

In 'n aparte vraag is gevra of die predikante hulle in die keuse van liedere ook deur die kerklike jaar laat lei. Tabel 5, Die kerklike jaar en die keuse van liedere, is 'n weerspieëling van hierdie respons.

Hier het ja die meeste steun by al drie groepe gekry, maar die orreliste en die lidmate is meer positief daaroor as die predikante self.

'n Aantal vrae het gehandel oor die voorlees van 'n lied of 'n gedeelte van 'n lied voordat dit gesing word (Van Rooy 2009:447-448). Die predikante is gevra of hulle hierdie praktyk volg en die orreliste en lidmate of hulle dit so verkies. Die respons word in Tabel 6, Voorlees van liedere, weergegee.

'n Klein meerderheid predikante volg hierdie praktyk, terwyl 'n groter meerderheid orreliste dit verkies en nog 'n groter meerderheid lidmate dit verkies.
TABEL 2: Liturgiese besonderhede van predikant na orrelis.

\begin{tabular}{ll}
\hline Tyd wanneer & Persentasie \\
\hline Voor of op die Donderdag voor die Sondag & 38 \\
Vrydag & 39 \\
Saterdag & 5 \\
Sondag & 18 \\
\hline
\end{tabular}

TABEL 3: Liturgiese besonderhede deur orrelis ontvang.

\begin{tabular}{ll}
\hline Tyd wanneer & Persentasie \\
\hline Voor of op die Donderdag voor die Sondag & 16 \\
Vrydag & 43 \\
Saterdag & 11 \\
Sondag vroeg & 8 \\
Direk voor die erediens & 22 \\
\hline
\end{tabular}

TABEL 4: Faktore wat die keuse van liedere bepaal.

\begin{tabular}{llll}
\hline Faktore & Predikante & Orreliste & Lidmate \\
\hline Aansluiting by liturgiese momente & $98 \%$ & $70 \%$ & $65 \%$ \\
Aansluiting by Skriflesing en prediking & $95 \%$ & $91 \%$ & $92 \%$ \\
Bekendheid van melodie & $78 \%$ & $64 \%$ & $23 \%$ \\
Aanleer van onbekende psalms & $25 \%$ & $27 \%$ & $15 \%$ \\
Repertorium van orrelis & $11 \%$ & $3 \%$ & $5 \%$ \\
Gehalte van gemeentesang & $28 \%$ & $39 \%$ & $7 \%$ \\
Bekendheid van inhoud & $30 \%$ & $39 \%$ & Nie gevra \\
\hline
\end{tabular}

TABEL 5: Die kerklike jaar en die keuse van liedere.

\begin{tabular}{llll}
\hline Moontlikhede & Predikante & Orreliste & Lidmate \\
\hline Ja & $50 \%$ & $76 \%$ & $72 \%$ \\
Nee & $4 \%$ & $3 \%$ & $5 \%$ \\
Gedeeltelik & $46 \%$ & $21 \%$ & $23 \%$ \\
\hline
\end{tabular}

TABEL 6: Voorlees van liedere.

\begin{tabular}{llll}
\hline Antwoord & Predikante & Orreliste & Lidmate \\
\hline Ja & $54 \%$ & $61 \%$ & $71 \%$ \\
Nee & $46 \%$ & $39 \%$ & $29 \%$ \\
\hline
\end{tabular}

TABEL 7: Voorlees van lied en begrip.

\begin{tabular}{llll}
\hline Antwoorde & Predikante & Orreliste & Lidmate \\
\hline Ja & $53 \%$ & $68 \%$ & $81 \%$ \\
Nee & $47 \%$ & $32 \%$ & $19 \%$ \\
\hline
\end{tabular}

TABEL 8: Verduideliking van keuse van liedere.

\begin{tabular}{ll}
\hline Antwoorde & Persentasie \\
\hline Altyd & 9 \\
Dikwels & 37 \\
Soms & 46 \\
Nooit & 8 \\
\hline
\end{tabular}

Die volgende vraag, wat in Tabel 7 weerspieël word, het gevra of die voorlesing van 'n lied die gemeente help om sodanige lied beter te verstaan. Die respons word in Tabel 7, Voorlees van lied en begrip, weergegee.

Die predikante se reaksie (Tabel 7) stem ooreen met dié van die vorige vraag (Tabel 6), terwyl die orreliste en lidmate nog sterker daaroor voel. Dit gaan in hierdie reaksie veral oor die beklemtoning van die inhoud deur die voorlesing. Die predikante is ook gevra of hulle die doel waarom 'n sekere lied gesing gaan word, aan die gemeente verduidelik. Die respons word in Tabel 8, Verduideliking van keuse van liedere, saamgevat. 
Hierdie respons verteenwoordig nie 'n sterk gevoel na enige kant toe nie. Indien egter gelet word op die response by die vorige vrae, behoort hierdie praktyk ook die kommunikasie deur die lied te bevorder.

Dit is belangrik dat al die deelnemers aan ' $n$ erediens moet verstaan wat gebeur en wat gekommunikeer word (Smit 2007:168). Omdat dit primêr die gemeente is wat in 'n kommunikatiewe verhouding met God staan en kommunikatiewe handelings in die erediens verrig, moet die liedere wat gesing word uit die hart kan kom. Die gemeente moet hulle daarmee kan vereenselwig, anders voldoen dit nie aan die basiese vereiste van die kerklied nie (Vos \& Müller 1990:96). Omdat 'n gemeente met God in gesprek is wanneer hulle sing, is duidelikheid ten opsigte van die betekenis van dit wat gesing word, baie belangrik. Die woorde van die lied moet 'n geskikte antwoord wees op die voorafgaande en moet die presiese bybelse getuienis en waarheid uitdra. Die antwoord van die gemeente en deelname aan die verskillende elemente van die erediens is baie belangrik. Die gemeente en elke hoorder moet dus kan hoor en presies verstaan waaroor die gesprek gaan. Dit is daarom die verantwoordelikheid van die kerk om toe te sien dat die liedere wat tydens die erediens gebruik word, aan hierdie vereistes voldoen. Dit moet bruikbaar wees vir alle moontlike antwoordgeleenthede en moet basiese toepassings van bybelse waarhede wees (Steinmann 1996:16). Predikante moet hulle daarop toespits om dit duidelik te stel waarom sekere liedere in die erediens gesing gaan word, om sodoende effektiewe kommunikasie te verbeter.

'n Volgende vraag het oor die keuse tussen alternatiewe melodieë gehandel, wanneer daar by 'n psalm die keuse is tussen twee melodieë in die Begeleiersboek of Koraalboek. Aan die predikante is vyf moontlikhede gegee wat hulle in volgorde moes rangskik (Van Rooy 2009:450). Uit die antwoorde was dit duidelik dat Geneefse melodieë baie maklik vervang is wanneer daar 'n alternatief is. Die keuses is sterk bepaal deur die melodieë wat die gemeente die beste ken of die melodie wat die predikant oordeel die bekendste is. Die vraag of die melodie by die woorde pas, het feitlik geen rol by die keuse van 'n melodie gespeel nie. Juis hierdie saak het ' $n$ negatiewe invloed op die wisselwerking tussen die teks en die melodie, deurdat singbaarheid 'n belangrike rol speel of die melodie by die teks pas of nie.

Hierdie vraag is ook aan die lidmate gevra (vgl. Van Rooy 2009:450), met weer 'n duidelike voorkeur vir bekende melodieë wat maklik sing.

In die onderhoude is die orreliste spesifiek gevra na hulle gevoel oor die alternatiewe melodieë wat in die psalmboek opgeneem is, en ook na ander alternatiewe melodieë. Alhoewel die orreliste oorwegend ' $n$ besondere waardering en selfs voorkeur vir die Geneefse melodieë het, besef hulle dat al die melodieë nie vir gemeentes so aanvaarbaar is nie. Lidmate verkies dikwels dit wat lekker sing. Selfs die predikante verkies dikwels die alternatiewe melodieë. Die orreliste staan nie afwysend teenoor die gebruik van die alternatiewe nie, juis ter wille van die gemeente se sang (vgl. Van Rooy 2009:451).

Die reaksie soos hierbo aangedui is, wys daarop dat daar in die GKSA 'n gebrek aan goeie oordeel is ten opsigte van die verband tussen die teks en die melodie. Hieraan word maklik toegegee soos blyk uit die standpunte wat deur die verskillende persone hieroor gestel is. Hoogstaande poëtiese en musikologiese standaarde moet, wat die kerklied betref, getemper word deur die lidmate se tradisionele en tydsbepaalde smaak (Vos \& Müller 1990:96). Die melodie behoort vir elke lidmaat toeganklik te wees (Smit 1999:51). $\mathrm{Al}$ is die melodie self van hoogstaande gehalte, kan dit ontoeganklik wees vir die gewone lidmaat wat nie oor 'n goeie kennis van musiek beskik nie (Smit 2007:526). Alhoewel die standpunte meriete het, kan dit daartoe lei dat die belang van die melodie in die kommunikasie deur die kerklied onderskat word - met 'n negatiewe impak op hierdie belangrike aspek van kommunikasie in die erediens.

Die saak van woord-toonverhouding in 'n kerklied en in die besonder ook in berymde psalms, sal in die toekoms besondere aandag moet ontvang. Dit speel 'n baie belangrike rol in die sukses en aanvaarding van 'n nuwe beryming. 'n Eenvoudige, memoriseerbare vorm speel 'n positiewe rol in hierdie verband. Besondere aandag aan hierdie saak was en is steeds een van die uitstaande kenmerke van die Geneefse melodieë, veral wanneer dit verband hou met die strofiese vorm. Iets wat die saak van die gebruik van die Geneefse melodieë in nuwe berymings soms problematiseer, is die verskil in die woordaksent van Frans en veral die Germaanse tale soos Afrikaans. Vir 'n kerklied om geslaagd te wees, moet die balans tussen die teks en die musiek steeds met die nodige omsigtigheid nagestreef word. Waar die ideaal bereik word, sal die lied steeds 'n positiewe bydrae in die liturgie kan lewer. Hierin moet na sowel die metriese as die ekspressiewe kant gekyk word.

Möller (2000:318) wys daarop dat een van die eerste vrae wat oor 'n nuwe liedteks gevra word, is of die teks gepas is. Mehrtens (1976:58) maak die opmerking dat dit die beste melodie is wanneer dit die teks in die besonder beklemtoon. Vos en Müller (1990:88) verwoord 'n algemene standpunt in hierdie verband, naamlik dat die funksie van die musiek daarop gerig moet wees om die gemeente in staat te stel om met die teks te identifiseer en hulleself met die sing daarvan uit te leef.

In die onderhoude wat met predikante gevoer is as deel van die empiriese ondersoek, is 'n algemene vraag oor die rol van die lied in die kommunikasie tydens die erediens gevra (Van Rooy 2009:455). Die reaksie hierop was positief. Die erediens as dialoog speel hier 'n besondere rol. Deur die lied kry die gelowiges kans om instemmend op die Woord te reageer, hulle skuld te bely en God te loof. Indien die liedere wat gebruik word vir almal ontvanklik en toereikend genoeg is om die volle spektrum van die geloofswaarhede te dek, 
kan die gelowiges hulle daarmee identifiseer en daardeur vind goeie kommunikasie dan plaas. Een predikant het daarop gewys dat dit sy ervaring is dat wanneer die melodie baie onbekend is, ' $n$ kommunikasiegaping ontstaan. Daar is egter baie liedere wat baie goed kommunikeer.

Die antwoorde uit die vraelyste en die onderhoude maak dit duidelik dat die plek van die lied in die liturgie hoog gewaardeer word. Dieselfde geld ten opsigte van die plek van die lied in die onderrig van die gelowiges. Die rol van die lied as kommunikasiemiddel word ook hoog aangeslaan, alhoewel die algemene gevoel is dat die saak nie ten volle in die praktyk tot sy reg kom nie. Hier kan die liturg 'n groter rol speel om die funksie van die gekose liedere tydens 'n erediens duidelik te maak.

\section{Slot}

Dit is duidelik dat liedere in die bybelse tyd gebruik is om die kommunikasie van die boodskap te bevestig en in te skerp. Die geskiedenis van die kerklied deur die eeue toon aan dat die belang van die melodie ter ondersteuning van die teks beklemtoon is, veral in die periode van die Reformasie en daarna. Die literatuur oor die funksie van die melodie toon aan dat die melodie die draer van die lied moet wees en daardeur 'n dienende funksie het om die gemeente te help om hulle met die teks te identifiseer. Die empiriese ondersoek het begrip by predikante, orreliste en lidmate vir hierdie funksie van die melodie getoon, maar in die praktyk is daar sekere leemtes. Hierdie leemtes het veral tot gevolg dat die bekendheid van 'n melodie dikwels 'n groter rol speel by die keuse van liedere as die inhoud - veral ten opsigte van die wisselwerking tussen inhoud en die melodie.

Die verskillende funksies van die kerklied moet steeds in gedagte gehou word, om die kommunikatiewe aard ten beste te gebruik. Volgens die aard van elke psalm moet dit so berym word dat funksies soos die ekspressiewe, kerugmatiese en gemeenskapsbouende funksies tot hulle reg kom. Hierdie sake moet ook in gedagte gehou word by die keuse of skepping van 'n melodie, sodat die melodie en die teks 'n hegte eenheid kan vorm. Daar moet gewaak word teen die verleiding om voortdurend nuwe liedere op bekende en geliefde melodieë te skryf, omdat dit nie tot 'n uitbreiding van die musikale gehalte van 'n liedboek bydra nie. Predikante het ' $n$ besondere verantwoordelikheid om die moontlikhede van kommunikasie deur die kerklied te bevorder. Dit kan gedoen word deur die verantwoorde keuse van liedere wat gesing word, die uitbreiding van die gemeenterepertorium, sinvolle samewerking met die orrelis en toeligting van die keuse van liedere wat tydens 'n erediens gesing word.

\section{Erkenning \\ Mededingende belange}

Die outeur verklaar dat sy geen finansiële of persoonlike verbintenis het met enige party wat haar nadelig kon beïnvloed in die skryf van hierdie artikel nie.

\section{Literatuurverwysings}

Barnard, W., 1991, 'Zingen in de kerk' in J. de Bruijn (red.), Psalmzingen in de Nederlanden: Vanaf de zestiende eeuw tot heden, bl. 13-16, Kok, Kampen.

Bingle, J.P., 2000, 'Die verhouding tussen openbaring, dogmavorming en doksa-uiting in die liturgiese lied', MTh-verhandeling, PU vir CHO.

Box, R., 1996, Make music to our God: How we sing the Psalms, Cromwell Press, Melksham, Wiltshire.

Bunners, C., 1995, 'Kirchenmusikalischer Gottesdienst', in H.C. Schmidt-Lauber \& K.H. Bieritz (hrsg.), Handbuch der Liturgik, Liturgiewissenschaft in Theologie und Praxis der Kirche, bl. 830-842, Evangelische Verlaganstalt/Vandenhoeck \& Ruprecht, der Kirche, bl. $830-8$ Leipzig/Göttingen.
Lens.

Craigie, P.C., 1983, Psalms 1-50, Word, Waco. (Word biblical commentary 19)

De Klerk, B.J., 2002, 'Liturgie, transformasie en die Afrika Renaissance', in M. Barnard \& N. Schuman (reds.), Nieuwe wegen in de liturgie: De weg van de liturgie-een vervolg, bl. 50-62, Meinema, Zoetermeer.

De Wit, J., 1996, 'Zingen op heilige toon', Werkmap Liturgie 30(5), 47-56.

Du Plooy, H.J.G., 2006, 'Geloof, musiek en taal (G.G. Cillié-gedenklesing)', Vir die Musiekleier 33, 40-54.

Erasmus, J.A., 2007, 'Prediking en spiritualiteit: 'n Homiletiese studie oor die verband tussen prediking en geestelike groei', PhD proefskrif, Noordwes-Universiteit. PMCid:2225470

Hobbs, T.R., 1985, 2 Kings, Word, Waco. (World biblical commentary 13)

Hoondert, M., 2003, “"Wachters op die morgen”: Muziek in de paaswake-Presentatie en evaluatie', Tijdschrift voor Liturgie 87(1), 64-75.

House, P.R., 1995, 1, 2 Kings, Broadman \& Holman, Nashville. (New American commentary 8)

Hull, K.R., 2002, 'Text, music, and meaning in congregational song', The Hymn 53(1), 14-25.

Kloppenburg, W., 2002, 'Woord en toon in de reformatorische kerkmuziek', in A. Vernooij (red.), Toontaal: De verhouding tussen woord en toon in heden en verleden, Hooij \& Sticht, Kampen, bl. 113-129.

Kloppers, E.C., 1997, 'Liturgiese musiek as kommunikatiewe handeling in 'n postmoderne era', DTh proefskrif, UNISA.

Kloppers, E.C., 2003a, 'Musiekbediening? 'n Prinsipiële begronding', Vir die Musiekleier 23 (30), 11-17.

Kloppers, E.C., 2003b, 'Verkondiging deur musiek: 'n Aspek van kreatiewe geloofskommunikasie', Hervormde Teologiese Studies 59, 65-84. http://dx.doi. org/10.4102/hts.v59i1.648

Kruger, D. \& Smit, E.J., 2001, 'Hoe moet dit dan wees?,Gedagtes en riglyne oor die aard en gebruik van die kerklied', Vir die Musiekleier 28, 14-23.

Lamberts, J., 2000, 'Liturgische muziek en zang', Tijdschrift voor Liturgie 84(3), 241-248.

Luth, J.R., 1986, Daer wert om seerste uytgekreten: Bijdragen tot een geschiedenis van de gemeentezang in het Nederlandse Gereformeerde protestantisme ca 1550 tot ca 1850, Deel 1 en 2, ThD proefskrif, Rijksuniversiteit te Groningen, Groningen, Van Den Berg, Kampen.

Mehrtens, F., 1976, Muziek op woorden, Ten Have, Baarn.

Mehrtens, F., 1982, Kerk en muziek, Boekencentrum, 's-Gravenhage. (Praktisch theologische handboekjes 18)

Möller, C., 2000, Kirchenlied und Gesangbuch, Quellen zu ihrer Geschichte: Ein hymnologisches Arbeitsbuch, Francke Verlag, Duisburg.

Mudde, W., 1977, 'Het kerklied van Luthersen huize, musikaal bezien', in W.G. Overbosch (red.), Een compendium van achtergrondinformatie bij de 491 gezangen uit het Liedboek voor de kerken, bl. 57-120, Prof. Dr G. van der Leeuwgezangen uit het Liedbo
stichting, Amsterdam.

Psalmboek, 2000, Die berymde Psalms in gebruik by die Nederduitse Gereformeerde Kerk, die Gereformeerde Kerke in Suid-Afrika, die Nederduitsch Hervormde Kerk van Afrika en Skrifberymings in die gebruik by die Gereformeerde Kerke in Suidvan Afrika en Skrifberymings in die gebruik by die Gere
Afrika, Calvyn Jubileumboekefonds, Potchefstroom.

Psalmboek, 2003, Die berymde en omgedigte Psalms en ander Skrifberyminge in die gebruik by die Gereformeerde Kerke in Suid-Afrika, NG Kerkuitgewers, Wellington.

Schelling, P., 1989, Muziek \& kerkewerk: Aandacht voor muziek in de opbouw van de geloofsgemeenschap, Boekencentrum, 's-Gravenhage.

Schulte Nordholt, J.W., 1977, 'Ambrosius (ong. 340-397)', in W.G. Overbosch (red.), Een compendium van achtergrondinformatie bij de 491 gezangen uit het Liedboek voor de Kerken, bl. 1129-1132, Prof. Dr G. van der Leeuw-stichting, Amsterdam.

Smit, E.J., 1999, 'Die transformerende krag van die gereformeerde kerklied in die huidige Suid-Afrikaanse konteks', ThM skripsie, PU vir CHO.

Smit, E.J., 2007, 'Die bydrae van die gereformeerde kerklied tot versoening en eenheid in 'n multikulturele Suid-Afrika', PhD proefskrif, Noordwes-Universiteit.

Speelman, W.M., 2002, 'Muziek en taal als stichters van cultuur: Semiotische analyse van de verwerkelijking van waarden in een lied', in A. Vernooij (red.), Toontaal: De verhouding tussen woord en toon in heden en verleden, bl. 131-146, Gooi \& Sticht, Kampen.

Steinmann, R., 1996, 'Gemeentesang en begeleiding', Vir die Musiekleier 23, 15-19.

Thevelein, I., 2004, 'Lied en muziek als verkondiging', Tijdschrift voor Liturgie 88(1), 139-142. 
Thompson, J.A., 1994, 1, 2 Chronicles, Broadman \& Holman, Nashville. (New American commentary 9)

Van Andel, C.P., 1982, Tussen de regels: De samehang van kerkgeschiedenis en kerklied, 2e dr., Boekencentrum B.V., 's-Gravenhage.

Van der Colf, A., 1997, 'Op soek na die postmoderne kerklied', Vir die Musiekleier 24, 19-23.

Van der Leeuw, G. \& Bernet Kempers, K. Ph., 1939, Beknopte geschiedenis van het kerklied, Wolters, Groningen.

Van Rooy, J.H., 2009, 'Die Psalmboek 2003 as kommunikasiemiddel in die liturgie van die erediens in die Gereformeerde Kerke in Suid-Afrika: 'n Himnologiese studie', PhD proefskrif, Noordwes-Universiteit.

Vernooij, A., 2002, 'Muziek en liturgie', in M. Barnard \& N. Schuman (reds.), Nieuwe wegen in de liturgie - een vervolg, bl. 95-114, Meinema, Zoetermeer.
Viljoen, F.P., 1990, 'Die betekenis van psalmois, humnois en odais pneumatikais in Kolossense 3:16 en Efesiërs 5:19', ThD proefskrif, PU vir CHO.

Viljoen, F.P., 2001, 'Die lied in die Nuwe Testament', Vir die Musiekleier 21(28), 8-13.

Viljoen, F.P., 2002, 'Die betekenis en funksie van die himnes in Openbaring 12-22', Verbum et Ecclesia 23, 558-574.

Viljoen, F.P., 2003, 'Die betekenis en funksie van die himnes in Openbaring 4-11', Acto Theologica 23(1), 213-237.

Vos, C.J.A. \& Müller, J.C., 1990, ‘Die sing van psalms in die erediens: 'n Kommunikatiewe handelingsteoretiese perspektief, Praktiese Teologie in Suid-Afrika 6(1), 86-98.

Vrijlandt, M.A., 1987, Liturgiek, Meinema, Delft.

Zijlstra, M., 2001, 'De vroege kerk en de middeleeuwen', in J. Luth, J. Pasveer \& J. Smelik (reds.), Het kerklied: Een geschiedenis, bl. 12-32, Mozaiek, Zoetermeer. 